\title{
FACTORING: ITS LEGAL ASPECTS AND ECONOMIC JUSTIFICATION
}

\author{
Herbert R. SitVERMan*
}

In 1947, twenty principal factoring companies in the United States processed sales aggregating over two billion dollars. Although this figure alone makes the factor a significant force in our national economy, many people do not fully understand his function as a stabilizing economic influence. For years, there has been discussion as to the legal aspects of factoring and his economic justification. This article proposes to show what the factor does, how he does it, and how his actions are beneficial to our economy as a whole.

Most contemporary discussion of the factor's economic justification probably arises from the fact that his functions have changed considerably with the passage of years. Factors were employed by the Romans, they were prominent in sixteenthcentury trade, and from the seventeenth century on they became increasingly active in industry. Originally, a factor was one who sold certain merchandise or property entrusted to him by the owner for that purpose, receiving a commission based on the amount received from sales. The term was often used in combination with the name of the merchandise sold, as "cotton-factor." The factor differed from the broker in that he was actually entrusted with the property to be sold, while the broker was employed only to make a bargain for it. ${ }^{1}$ For some time, then, a factor was regarded generally as a selling agent, and the word was used frequently in the importing business, the textile industry, and in the marketing of agricultural commodities. The term "del credere agent" was commonly used to express the obligation assumed by factors, when selling on credit, to hold themselves liable if the purchaser failed to pay; and "del credere commission," accordingly, defined the increased compensation chargeable by the factor as a result of the extra risk thus assumed.

With the advent of the twentieth century, the functions of factors were narrowed, particularly in the textile industry. Gradually, some factors began to abandon part of their original activities, leaving to commission merchants the selling and merchandising of mills' outputs, and concentrating themselves on financial functions and credit responsibility. This occurred shortly before World War I; today, the term "factoring" is most often used to refer to a specialized service of credit checking and of financing the producer and distributor of merchandise. Virtually all factors have ceased to concern themselves with selling.

\footnotetext{
- B.S. 1932, New York University; IL.B. I935, Brooklyn Law School. Member of the New York bar. Vice President and Director, James Talcott, Inc. President, National Conference of Commercial Receivable Companies, Inc. Contributor to accounting and business periodicals.

${ }^{2}$ Parsons on Contracts I0o (gth ed. 1905).
} 
The main functions of the factor today, then, are as follows: (I) purchasing accounts receivable; (2) guaranteeing the seller against customer credit failures; (3) billing, ledgering, and collecting the receivables; and (4) financing clients' operations, either by advances before maturity against the accounts purchased, or by loans on the security of stocks on hand or in the process of manufacture. Although this is an imposing list, as such, it gives the person unfamiliar with the factor's operations no real indication of the factor's complex activities. In order to understand how the factor operates as a stabilizing economic force, it is necessary to examine some of his functions in actual operation.

\section{The Factor's Economic Justification}

The rise of the factor in the textile industry was noted particularly in an article by Roscoe T. Steffen and Frederick S. Danziger (both of the Yale Law School) in the May, 1936, issue of the Columbia Law Review. ${ }^{2}$ The authors apparently viewed the factor's position and his functions with the natural skepticism that is the result of incomplete information or understanding. They wrote, at one point: '... once again there has been introduced a 'middleman,' and that, to no discernible economic good." Later, in discussing the legal aspects of factoring, they went on to say:

... the courts through the years have given [the factor] powerful support in the attainment of his purposes. . . . In the last quarter century there has been doubt; the old confident singleness of purpose, the further "promotion of trade," has been lacking at times. Or possibly the doubt has been whether the present factor contributes substantially to that end. Though he appears to show a profit, there has been a feeling that profit, like virtue, is its own reward-and that the courts need no longer be unduly solicitous of his affairs. 4

It is only fair to Messrs. Steffen and Danziger to point out, in the first place, that many changes have occurred in the twelve years since their article was written. As we shall see, the factor has shown himself, particularly during lean years, to be so valuable to many industries that even the most violent critic could not now with any conscience condemn him.

Any consideration of the Steffen and Danziger article in the light of actual events must inevitably lead to the conclusion that the authors possibly were interpreting history according to a concept too broad to be entirely accurate. It is true that the factor is a middleman-but to condemn him as such is to overlook the beneficial, not to say vital, effects of the merchandising, styling, and service organizations which have done so much to stimulate and develop world trade. A closer examination of the factor will serve to justify his position.

It can be said, generally, that the factor's main activities which are beneficial to industry as a whole fall into five categories:

r. By advancing money so that the manufacturer can continue his operations,

${ }^{2}$ Steffen and Danziger, The Rebirth of the Commercial Factor, 36 Cox. L. Rev. 745 (1936).

${ }^{2}$ Id. at $746-747$.

1d. at 768-769. 
the factor aids in keeping up the level of employment, and in maintaining a steady flow of the manufacturer's commodity;

2. By supplying funds to the manufacturer of seasonal products, the factor enables the seasonal business to smooth out into a year-round operation, thus eliminating off-season unemployment;

3. By supplying funds and advice based on long experience, the factor enables a business to expand at an even pace;

4. By supplying funds needed for a change in ownership of a business, the factor guarantees the continuation of the business for the benefit of its employees;

5. By acting decisively, judicially, and authoritatively in credit practice and advice, the factor exercises a stabilizing influence on the country's economy as a whole.

As a preliminary to any discussion of the factor's activities, his credit operations should be discussed briefly. To begin with, the factor organizes the extension of credit. By controlling indiscriminate and careless credit practices he minimizes speculation in the accumulation and distribution of goods. Factors have policed credit misdemeanors and fraudulent credit practices simply by standardizing credit procedure.

Perhaps the principal function of modern factoring is in its aid to the small and middle-sized business concern. The large business organization usually is in a position to factor itself. The factor, by putting the moderate-sized company on a cash basis and freeing it from credit risk, lifts it to a position comparable to that of the large company. The spectacular growth of factoring in recent years may be largely attributable to two causes: first, the need for credit advice and credit warranty to manufacturers who do not have the organization to handle their own credit problems efficiently; and second, the need for working capital which arises at one time or another in the conduct of most businesses.

According to a survey made by the United States Department of Commerce for the first quarter of $1946,98.2$ per cent of the businesses in the United States employed less than 500 people, and these companies can be classified as small businesses. Because small businesses are often under-capitalized, it becomes necessary, if they borrow at all, to do so on a secured basis. The 300,000 to 500,000 new enterprises which come into existence each year are sometimes pioneered by men who have had little or no experience in financing a new business, and consequently begin their operations under-capitalized. As these businesses grow, even if they are successful, they find themselves constantly in over-extended positions, and often have difficulty in obtaining the credit they need to survive. Depository banks, circumscribed by law, cannot or will not make loans to them, at least in the amounts they require.

In a 1947 report, the Research Institute of America reported that bank credit practices have undergone significant changes, becoming tighter and more careful. "This comes at a time," the report stated, "when more and more companies are facing higher inventory costs, bigger payrolls, slower collections, and will there- 
fore need extra cash to tide them over. Accounts receivable financing is particularly good in certain cases: as where small or medium-sized companies are looking for short-term loans, especially where the companies are growing fast and need working capital. . . . Many banks aren't interested in lending money on this basis. The loans are often for small amounts and involve a lot of handling. ... Factors take over the collection of accounts, which banks cannot do.... They may even stand the loss of accounts in the event of defaults. Also, the borrower is freed of considerable bookkeeping expense."

The benefits offered by a factor to the factored client can best be illustrated by a group of case histories taken from our own files.

During the depression, one large textile mill was forced to suspend operations because of losses. Many people of the town in which the mill was located were dependent upon the mill for their livelihood, and the abandonment of the mill would have resulted in considerable hardship for the community. By a combination of a government loan and a revolving credit agreement set up by the factor, together with the employment of more efficient management, the mill was able to keep running and ultimately worked out of its difficulties.

Another interesting example of the uses to which a factor can be put by a client can be found in the case of a large cotton mill which owned a smaller mill devoted to the manufacture of rayons. For business reasons, the owners of the large mill wished to separate the rayon business from their cotton operations, and therefore put the rayon mill up for sale. It would have been possible for the owners to sell the machinery and equipment of the smaller mill outright for dismantling purposes; if this had been done, the rayon operation would have ceased to function, and hundreds of people would have been thrown out of work.

The factor, realizing the potential demand for rayons, advised the mill owners not to sell the equipment for dismantling, but rather to attempt to sell the mill as a coordinated unit. This was done, and the mill was sold to an operator who financed it with his own capital plus factor's funds advanced against the security of the mill buildings and machinery. With the factor's assistance, this operation was turned into a successful enterprise.

The sale of rayon fabrics provides an excellent example of the manner in which the factor exercises a stabilizing effect upon present-day economy. In the past, the sale of rayons was primarily a spot business. Today, a converter will receive his allotments three or four months ahead and accordingly will sell three or four months ahead, subject to his factor's approval. Naturally, this adds considerably to the factor's risk; yet from the mill's point of view, the situation could hardly be more desirable. As a result of the factor's efforts, the following results are obtained: (x) a continuity of business is created; (2) the client's employees are protected; and (3) there is a constant production flow of the product to the public.

As a general rule, the lengthening of the time for production of the finished product from the raw commodity simultaneously lengthens the period of forward 
checking. Yarns and raw wools, for example, may be checked as far as six months ahead. Current conditions illustrate clearly the established factor's ability to check credits far beyond the capacity of the individual manufacturer. Over a long period, the factor will have built up an organization staffed with experienced personnel, and with sources of information available which the manufacturer would not have within his own organization.

The factor provides a constant flow of funds for working capital regardless of the fluctuating balances of outstanding receivables, or of the change in selling terms. For example, as sellers' markets change to buyers' markets, trade terms lengthen. Simultaneously, the factors' commitments lengthen: if the terms of payment change from ten to seventy days, the factor will guarantee payment at the extended due date. In seasonal businesses, such as the manufacture of bathing suits, outdoor furniture, or ice skates and sleds, the practice is to give datings on invoices extending as far ahead as five or six months. The factor invariably will honor such datings, and because of this the manufacturer is enabled to plan a year-round production schedule with employment at an even level, instead of seasonal layoffs and overtime employment.

The factor often has been valuable in helping a businessman plan an expansion program. When a manufacturer evinces his desire to expand, the factor will have an auditor prepare a production and cash-flow sheet, so that the manufacturer can visualize the future scope of his operation and make certain that he can meet his obligations as they mature, and still maintain an adequate margin of safety. In other instances, the factor will render his client a valuable research service by conducting surveys to determine whether or not the product is likely to be received favorably by the public, and, if not, what changes must be made in order to achieve favorable public reception. The factor is also in a position to help decide whether or not his client's product and its sales price are competitive.

The way in which the factor's knowledge of a certain field can aid his client is illustrated by the situation of a man who was engaged in selling waste paper to paper mills during the I930's. This man was anxious to have his credits guaranteed, owing to the uncertain financial condition of many paper mills with which he was dealing at the time. With the coming of war, the demand for paper of all types increased rapidly. Concurrently, there was a sharp decline in imports of the wood pulp so necessary to paper manufacture; this, of course, put waste paper, as a substitute for wood pulp, in even greater demand. The seller of waste paper approached his factor and asked if it might not be profitable for him to purchase a paper mill, reasoning that he could then supply waste paper to his own operation. The factor advised against this move, pointing out that the seller had had no experience in operating a mill. The seller agreed, and later merged his business with that of an existing paper mill which already possessed competent management. The factor advanced part of the funds necessary to consummate this transaction. In the following years, both businesses prospered. Today the merged company is one of the leading manufacturers of kraft paper. 
The factor often aids in the establishment of partnerships. In one recent case, an elderly man with an established business manufacturing small motor parts decided to sell a $5^{\circ}$ per cent interest to a younger man, with the idea that the latter could run the operation and relieve the original owner of some of the burdensome detail. The new man put in his share of the price, as much as he could afford, and a factor advanced the rest against the security of liens and mortgages. The original owner, in agreeing to this, was influenced considerably by the fact that the factor would exercise active supervision over customer credits. Because of this, he would have some assurance that the new interests would carry on the sale of the company's products in an approved manner.

A rather different instance in which the factor has aided in the change of ownership of a company is provided in the case of one mill which had been controlled for some time by stockholders who were not active in the actual management of the business. An individual who began his career with this company as a salesman, and ultimately worked his way up to vice-president, then president, finally found himself in a position to buy the company outright. A bank could not lend this man the money necessary to purchase the company. A factor, on the other hand, could enable him to buy the company by advancing funds adequately secured. This was done, and the factor not only advanced the money but also advised and assisted in the conduct of the business. Although the factor now concentrates on financial aspects, he still retains close association with the production and merchandising problems of his clients.

The factor's fees are quite nominal when one considers the assumption of the risk of credit losses, the volume of business handled, the hundreds of thousands of invoices processed, and the multifarious accounting and bookkeeping functions the factor performs. Fees are based on a small percentage of the annual sales volume.

\section{Legal Aspects of Factoring}

In order to discuss the legal aspects of factoring, it is necessary to refer again to its actual operations. Johnfritz Achelis, President of the Commercial Factors Corporation, has clarified them with this statement:

... A commercial factor does not lend against accounts receivable. He buys them outright, with no recourse to the client. If the account goes bad the factor is the losernot the mill, nor the converter, nor the selling agent whose accounts have been factored. In order to assume this risk the factor must, of course, pass on all credits. He also does his client's accounts-receivable bookkeeping, and does the collection. As shipments are made, the client is credited with all but a small reserve which is temporarily set up to absorb returns, allowances for faulty merchandise, and the other contingencies which arise. But this is in no respect a reserve for bad debts. ...

As we have seen, advances made against the pledge of merchandise play an important part in the factor's operations. For this reason, the development of the law concerning the factor's security in such operations is of primary interest. As 
early as 1695, the English Parliament passed an act providing for licensing and regulating terms of credit, and governing the time and the method of settlement between client and factor. ${ }^{5}$ By 1823 , an act had been passed which provided the framework on which factor's lien statutes ultimately were enacted in the United States. ${ }^{\circ}$

Perhaps because there has always been a large number of concerns engaged in factoring in New York, the first law to facilitate factor's liens was passed in that state. The antecedents of many factors were representatives of foreign mills, who had settled in New York because of its position in import trade and its prominence as a textile distributing center and sales market. As some of these houses' functions became more clearly financial, they retained, with advantage, their proximity to the selling agencies. Concurrently, there developed in New York City a group of credit-rating and other service agencies that made the function of a factoring company more economical in that city.

In Igro, the New York legislature passed a bill providing that liens upon merchandise or the proceeds thereof, when created by agreement for the purpose of securing advances made or to be made, should not be void, provided only that the name of the lienor and his designation as factor should be posted at the entrance of the place where the merchandise was stored. ${ }^{7}$ This bill was vetoed by Governor Charles Evans Hughes on the ground that "it would . . . facilitate secret liens and fraudulent transactions." 8

In I9rx, Assemblyman (later Governor) Alfred E. Smith reintroduced this bill, with amendments requiring that a notice be filed setting out briefly the name and place of business of the lienor, the name of the person creating the lien, his interest in and the general character of the merchandise, and the time for which the agreement was to run. This bill then became law. It now was possible for a creditor by a search of the records to determine whether or not his debtor had created a lien in favor of a factor. In addition, credit-rating houses and funancial institutions generally insisted upon full and complete financial statements, which would disclose not only whether or not receivables were factored but also whether merchandise was pledged.

It soon became clear that the Factors' Lien Act did not fully cover all contingencies. Although the Act of IgII enabled the factor to obtain a valid lien on goods upon which he had made advances (provided he met the necessary requirements of the statute), in cases where he limited his transactions to the purchase of accounts receivable, and made no merchandise advances, he did not find it necessary to comply with the statute. Therefore, when merchandise was returned to a fac-

58 \& 9 Wrs. III, c. 9 (I695).

${ }_{4} 4$ GEO. IV, c. 83 (1823).

${ }^{7}$ New York State Assembly Bill No. 226r.

${ }^{8}$ The Legislative history of this bill, including Governor Hughes' veto memorandum of June 25 , 1910, from which the above is quoted, and the debate quoted hereafter on introduction of the I9II bill, is available in the brief of the appellant, and in the amicus curiae briefs of the General Motors Acceptance Corporation and Commercial Investment Trust Corporation, submitted in the case of Utica Trust Co. v. Decker, 244 N. Y. 340, 155 N. E. 665 (1927). 
tored client, and was on his premises, the factor's lien would not attach to such merchandise.

The uncertainty of the courts' interpretations of the Factors' Lien Act indicated further amendment, and in I93 it again came before the state legislature. ${ }^{0}$ The I93I amendment made the following basic changes in the Act: ( $r$ ) it defined "factor" as "including any consignee or pledgee who advances money on goods consigned or pledged to him whether or not he is employed to sell them"; and (2) it provided that such a factor has a "continuing general lien" upon all goods consigned to him whether or not in his possession, and on any accounts receivable or other proceeds resulting from a disposal of the goods-that is, where he has an agreement to that effect. The first change was necessary because the courts had shown increasing reluctance to grant a factor a lien which they felt belonged only. to one charged with selling goods, despite the fact that the basic function of the factor had changed since the early days of commission selling.

The amendment overcame a second inequity by granting the factor a lien where the goods were not in the possession of his borrower. This was accomplished by the provision that the factor should have a lien on goods consigned or pledged to him whether in his possession or not. In so far as the actual operations of the textile industry were concerned, this was a very important portion of the amendment, because of the decentralized nature of its operations.

Shortly after I9r8, the silk and cotton converter had come into prominence. It was the converter's practice to send his goods to a dyer or finisher for processing. It was against such goods that the factor had advanced monies, and he naturally expected that these goods would be security for his loan. The I93I amendment made it possible for the factor to extend his lien to the goods in process, "whether in his possession or not." Therefore, even though the factor had possession of the goods-which in effect gave him a common-law possessory lien-he was not obliged to file a notice and post a sign in compliance with the Factor's Lien Act to validate this lien. It was apparent, therefore, if the Act was to conform to the actual working conditions of the factoring business, that further changes were necessary.

By the amendment of 1935, the New York State Legislature reinvoked the common-law possessory lien when it provided that "When any factor or other lienor, or any third party for the account of any such factor or other lienor, shall have possession of goods and merchandise, such factor or other lienor, shall have a continuing general lien, as set forth in the first paragraph of this section, without filing the notice and posting the sign provided for in this section."10 It was always contended by the proponents of the Factors' Lien Act that the recording and posting of the notice of lien would preclude unsecured creditors from being misled as to the ownership of merchandise stored in the premises of a company which was factored. Unless such notice was given, a creditor would believe that any merchandise on the premises of the debtor would be his property, free of lien. However,

N. Y. Pers. Prop. LAW $\$ 45$, as amended by L. I931, c. 766 .

${ }^{20}$ N. Y. Pers. Prop. Law, $\$ 45$. 
when the goods were not in the possession of the debtor, but were in the possession of the factor, or any third person acting for the factor, a creditor could not be misled.11

Since New York had been the pioneer in enacting a Factor's Lien Act, great stress was laid on perfecting the statute in this state. It was natural to suppose that as other states sought to enact such statutes they would benefit from New York's experience, and that they would be influenced by the decisions interpreting the New York act.

At present, twenty-one states have enacted factors' lien acts. The table on pages 602 and 603 summarizes these statutes and shows the essential differences between them. ${ }^{12}$

Some of the outstanding differences between the acts of the various states are as follows:

Connecticut is the only state that does not require a master factoring agreement.

Michigan, North Carolina, and Vermont restrict the act to manufacturers and processors.

Virginia and West Virginia restrict it to manufacturers only.

Texas restricts it to wholesalers only.

All states require that a notice be filed in a recording office, but Alabama, Delaware, Maryland, Massachusetts, Michigan, Minnesota, Ohio, Rhode Island, South Carolina, and Vermont do not require the posting of a sign.

Considerable confusion has arisen as to the necessity of obtaining a formal pledge or consignment of individual lots of merchandise in order to have a perfected fac-

${ }^{21}$ A typical clause in a present-day factoring contract covers this point as follows: "The undersigned hereby assigns and sells to you as absolute owners and you hereby purchase from the undersigned and without recourse to the undersigned except as set forth hereafter, all accounts, notes, bills, acceptances or other forms of obligation (herein collectively termed "receivables") hereafter created, acceptable to you, and represented by the undersigned to be bona fide existing obligations of its customers arising out of and acquired by it in the ordinary course of its business, which are due and owing to the undersigned without defense, offset or counterclaim. The undersigned further sells and assigns to you all merchandise represented by such receivables that may be returned by customers. It further assigns and transfers to you all its title and/or interest in the merchandise represented by such receivables and all its rights of stoppage in transit, replevin and reclamation. Any merchandise so recovered shall be treated as returned merchandise. . . The undersigned hereby warrants to you that the customer in each instance will accept the merchandise sold, and the invoice therefor without dispute as to price, terms, quality, or in any other respect, and will notify you piomptly of all such disputes and/or claims which will be setuled by the undersigned at its own expense; but you are to have the right at all times of adjusting all claims and disputes directly with the customer or other complainant, including the right to take possession of and to sell or cause to be sold any merchandise which may have been returned or rejected by the customer, at such prices and upon such terms as you deem advisable, and to charge the deficiencies, costs and expenses thereof to the undersigned. In addition to any other rights to which you are entitled under this agreement, where there is such dispute and/or claim, you may charge such disputed amounts to the undersigned. The charge back of any such receivable shall not be deemed a reassignment thereof and title thereto and to the merchandise represented thereby shall remain in you until you are fully reimbursed. If any remittances are made directly to the undersigned, the undersigned shall hold the same as your property and immediately deliver to you the identical check, monies or other form of payment received, and you shall have the right to endorse the name of the undersigned on any and all checks or other form of remittance received where such endorsement is required to effect collection. If at any time you shall be required to pay any state or federal sales or excise tax on sales hereunder, the undersigned will repay to you the amount of tax so paid by you."

${ }^{12}$ Reproduced by courtesy of Joseph S. Fechteler, C.I.T. Financial Corporation. 
602

Law and Contemporary Problems

\begin{tabular}{|c|c|c|c|c|c|c|c|c|c|c|c|}
\hline 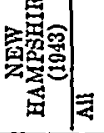 & 善 & $\mid \stackrel{3}{\not-1}$ & $\mid$ & & 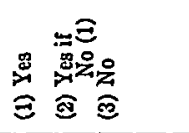 & 惡 & | & 惢 & 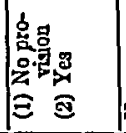 & 蛋 & 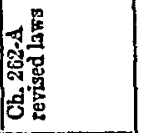 \\
\hline 葋 氪 & 镸 & 㞼 & 量 & & 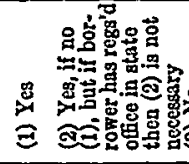 & 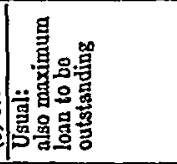 & 僮 & 2 & 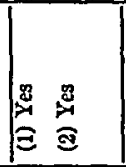 & 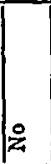 & 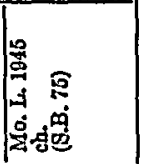 \\
\hline 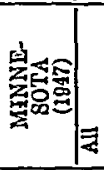 & 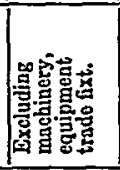 & $\div$ & 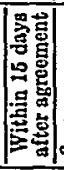 & & 芯总艺 & 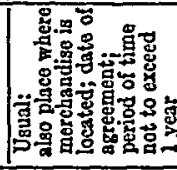 & 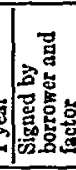 & 运 & 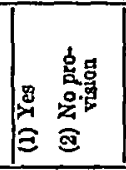 & D & 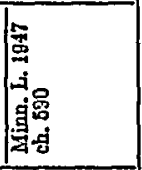 \\
\hline 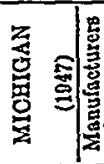 & 辛产 & 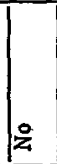 & 畺 & 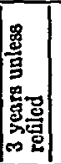 & 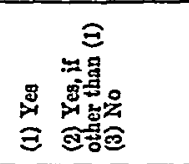 & 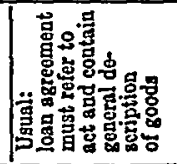 & $\mid$ & : & 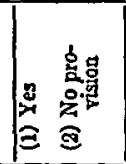 & 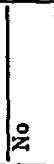 & 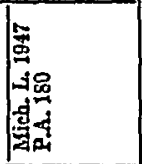 \\
\hline 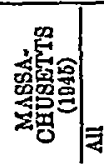 & 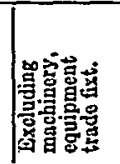 & 울 & $\mid$ & 譄 & 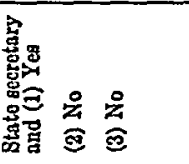 & 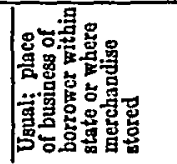 & 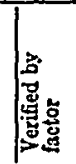 & 2 & 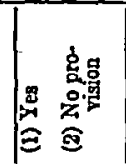 & 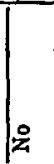 & 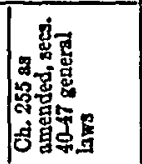 \\
\hline 影 & 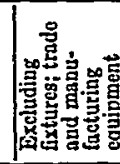 & 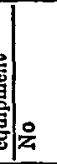 & 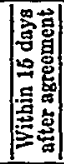 & 篓 & 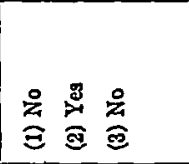 & 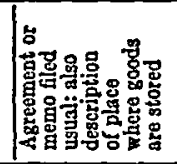 & 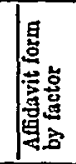 & 1욜 & 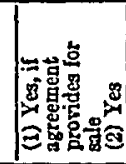 & 3 & 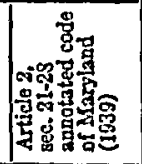 \\
\hline 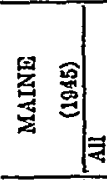 & 善 & 蛹 & 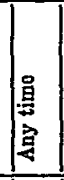 & 量 & 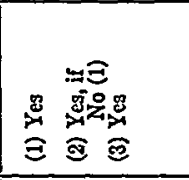 & 畺 & 害 & 2 & 量 & $\int_{-1}$ & 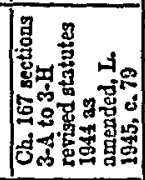 \\
\hline 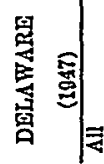 & 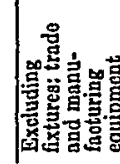 & 횧유 & 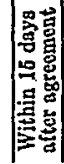 & 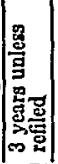 & 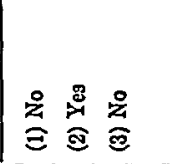 & 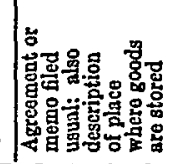 & 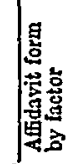 & 胥 & 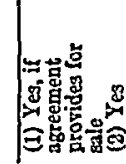 & 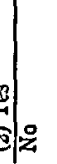 & 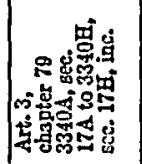 \\
\hline 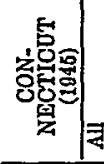 & 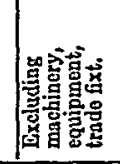 & 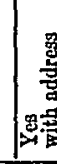 & 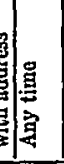 & 苋 & 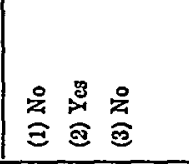 & 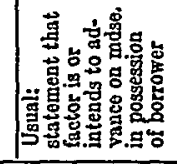 & 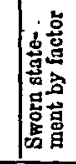 & 20 & 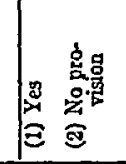 & 里 & 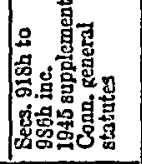 \\
\hline 争 & 总 & 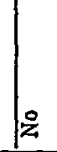 & 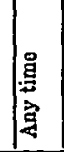 & 总 & 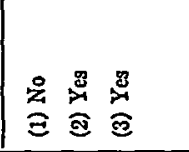 & 㽬 & 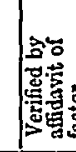 & $\underline{\mathrm{g}}$ & 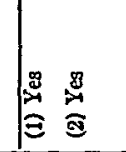 & झ & 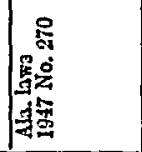 \\
\hline 愿 & 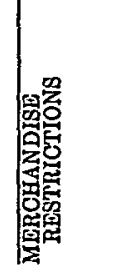 & 愿 & | & 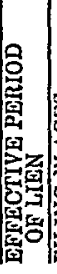 & 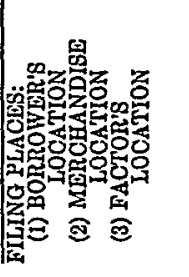 & 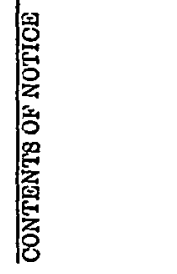 & 恿 & 通 & 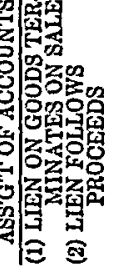 & 彭 & 要 \\
\hline
\end{tabular}


Factoring: Its Legal Aspects and Economic Justification

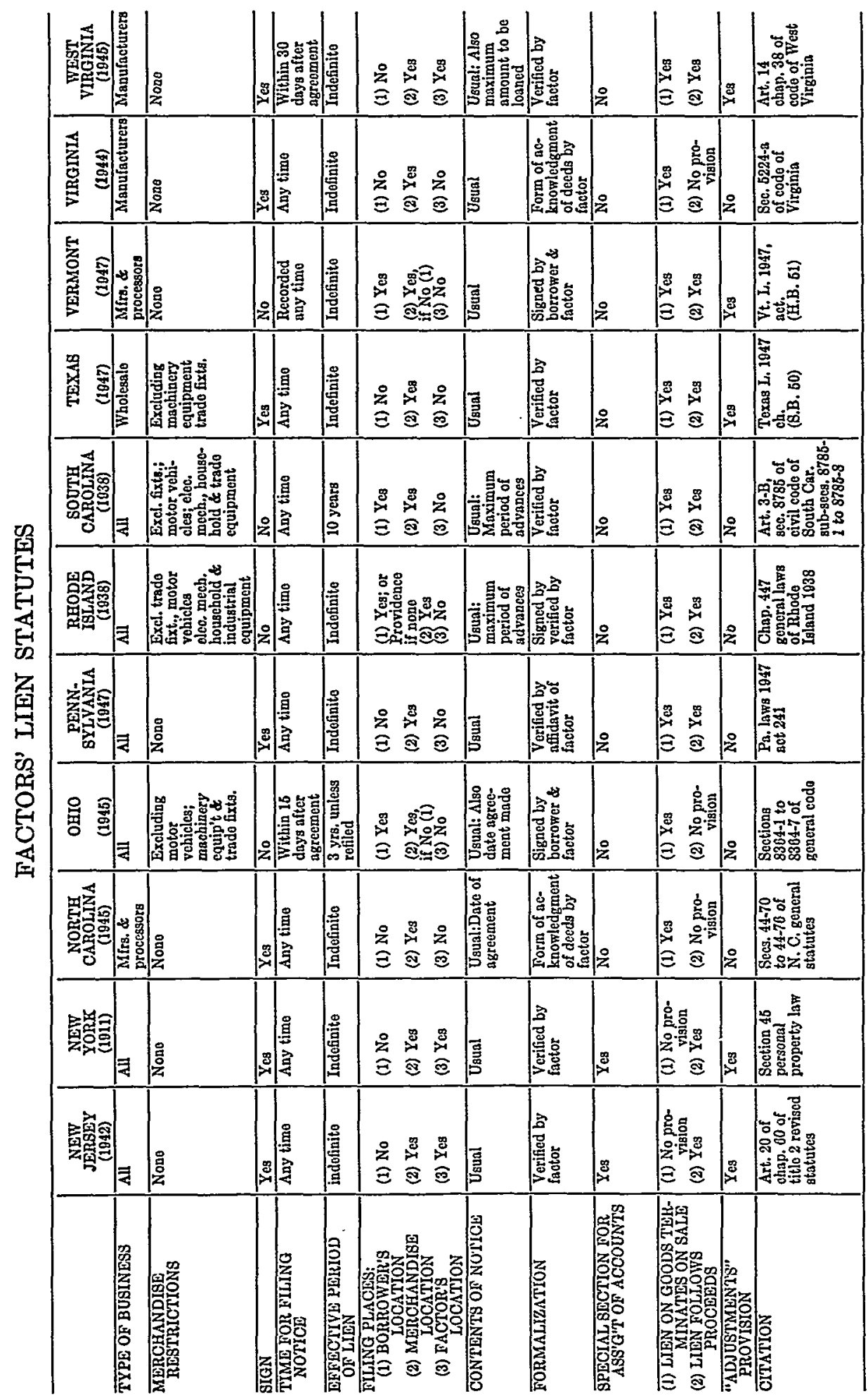


tors' lien. Most states provide that the lien shall extend to all goods. In New York, the language on this phase reads, "... . all goods and merchandise from time to time consigned to or pledged with [the factor]...."13 It would appear that the better practice would dictate that full compliance with the statute should require a formal pledge or consignment of each lot of merchandise. The Rhode Island and South Carolina statutes specifically provide that the lien shall attach only to such merchandise as has from time to time been agreed to by written statements identifying the merchandise and the proceeds thereof.

Another point of difference involves the extent of the factor's lien. For example, does the factor have a lien only upon the goods themselves, or does the lien likewise attach to the proceeds of the goods when they are sold? The lien extends only to the pledged goods, and is released by their sale in the regular course of business, in Connecticut, Massachusetts, Michigan, Minnesota, North Carolina, Ohio, and Virginia. In Alabama, Maine, Missouri, New Hampshire, Pennsylvania, Rhode Island, South Carolina, Texas, Vermont, and West Virginia the lien extends to the goods and their proceeds. The Pennsylvania statute, which is typical, adequately covers this situation by the following text:

When merchandise subject to the lien provided for by this act is sold in the ordinary course of the business of the borrower, the purchaser shall take the said merchandise free and clear of the lien of the factor, whether or not the purchaser has knowledge of the existence thereof, and the said lien shall without further act of the factor attach to any proceeds arising out of such sale, and shall be valid in law as, and enforceable against, all subsequent purchasers, assignees, transferees, pledgees, and other creditors of the borrower. 14

The extension of the "follow through" theory of the factor's lien in the various stages may be summarized as follows: (I) the lien originally exists on the merchandise; (2) it then passes to the proceeds of sale, by which is usually meant the cash received in exchange for the sale of the merchandise; or (3) it passes to the account receivable resulting from the sale of the liened merchandise. In Maryland and Delaware, the lien will pass to the accounts receivable or cash proceeds only if the factor's lien agreement so provides. However, in New York, New Hampshire, and New Jersey by statute, and even in the absence of an agreement to that effect, the lien will pass from the goods to the proceeds or the accounts receivable resulting from the sale of the pledged goods.

The most recent decision in New York involving a factor's rights under a factor's lien illustrates the necessity for strict compliance with the requirements of factor's lien acts. The decision was rendered by a referee in bankruptcy in the Southern District. The factor had filed his notice of lien pursuant to the Act. He posted the notice on the outside of the double door of the borrower's loft building, in such a manner that it could not be seen when the doors were open during business hours. The referee decided that the sign had not been conspicuously placed as required by law; the purpose of the Factor's Lien Act, he indicated, was to have

${ }^{13}$ N. Y. PERs. Prop. Law $\$ 45$.

${ }^{14} \mathrm{~Pa}$. Laws 1947, No. 24I, \$4. 
the sign placed so that it could be seen during business hours, and in such a manner that would make it easily discernible by all creditors. The court, therefore, denied the lien.

\section{Purchase of Accounts Recervabie}

In recent times, many of the problems concerning the factor's right to assert a lien on merchandise have been correlated with questions as to a factor's rights to accounts receivable arising from the sale of merchandise, whether or not previously pledged to the factor. Over a period of years, the courts have resolved this question substantially. It may now be well to consider the primary function of the modern factor-that is, the purchase of accounts receivable without recourse to his client.

A summary of the law on the validity of an assignment or sale of accounts receivable in the various states is as follows: $:^{15}$

r. The American non-notification rule prevails, either by statute or decision, in the following twenty-one states:

$\begin{array}{ll}\text { Alabama } & \text { New Hampshire } \\ \text { Arkansas } & \text { New Jersey } \\ \text { Connecticut } & \text { New York } \\ \text { Illinois } & \text { North Dakota } \\ \text { Indiana } & \text { Oregon } \\ \text { Kentucky } & \text { Rhode Island } \\ \text { Maine } & \text { South Dakota } \\ \text { Maryland } & \text { Virginia } \\ \text { Massachusetts } & \text { West Virginia } \\ \text { Michigan } & \text { Wisconsin }\end{array}$

2. The English notification rule prevails, by decision, in the following four states.
Louisiana
Tennessee
Mississippi
Vermont

3. Bookmarking is required in the following two states:

Pennsylvania Georgia

4. Recording is required in the following twelve states:

$\begin{array}{ll}\text { California } & \text { Ohio } \\ \text { Florida } & \text { Oklahoma } \\ \text { Colorado } & \text { South Carolina } \\ \text { Idaho } & \text { Texas } \\ \text { Missouri } & \text { Utah } \\ \text { North Carolina } & \text { Washington }\end{array}$

${ }^{15}$ Reproduced by courtesy of National Conference of Commercial Receivable Companies, Inc., as compiled for their Compendium of Commercial Laws. 
5. The law in the ten remaining jurisdictions (including the District of Columbia) remains unsettled:

$\begin{array}{ll}\text { Arizona } & \text { Nebraska } \\ \text { Iowa } & \text { New Mexico } \\ \text { Delaware } & \text { Nevada } \\ \text { Kansas } & \text { Wyoming } \\ \text { Montana } & \text { District of Columbia }\end{array}$

As a matter of mechanics in the operation of a factored account, it is the custom that invoices evidencing the purchased accounts receivable mailed to the customer either by the factor or directly by his client, are imprinted clearly on the face with a legend in substantially the following form:

\section{For Value Received This Account Is Assigned to, OWned by and Payable Onzy to \\ James Talcotr, INC. 225 Fourth Avenue NEw York 3, N. Y.}

Since notification of the assignment has thus been given to all parties, the factor need not be concerned with the rights of successive assignees in either non-notification or notification states.

The bookmarking statutes enacted in Pennsylvania and Georgia are intended to validate the non-notification assignment of receivable transactions. In Pennsylvania the statute provides that "notification to the principal debtor of the fact that an account owing by such principal debtor has been sold, assigned, transferred or pledged shall be sufficient to make such sale, assignment, transfer or pledge valid in law as, and enforceable, against all subsequent purchasers, assignees, transferees, pledgees, execution, attaching or other creditors, notwithstanding the fact that a record of such sale, assignment, transfer or pledge is not made upon the books of account or other records of the seller, assignor, transferor or pledgor."10

The necessity for perfecting the form of the assignment or transfer of accounts receivable was emphasized by the revision of the federal Bankruptcy Act made in I938 under the Chandler Act of that year. On this point, the language of the Act is as follows. ". . . a transfer shall be deemed to have been made at the time when it became so far perfected that no bona-fide purchaser from the debtor and no creditor could thereafter have acquired any rights in the property so transferred superior to the rights of the transferee therein, and, if such transfer is not so perfected prior to the filing of the petition in bankruptcy or of the original petition under chapter I0, Ir, 12 , or $\mathrm{I}_{3}$ of this title, it shall be deemed to have been made immediately before bankruptcy."17

The case of Corn Exchange National Bank \& Trust Company v. Klauder ${ }^{18}$

${ }^{10}$ Pa. Laws 1941, No. 255, p. 606.

${ }^{17} 52$ STAT. 869 (1938), II U.S.C. $596($ a) (1940).

${ }^{18} 3 \times 8$ U. S. 434 (1943). 
furnishes an interesting example of the application of this revised Section 6oa of the Bankruptcy Act. Pennsylvania enacted a bookmarking statute in 1941; prior to that time the law of Pennsylvania required that, in order to perfect the assignee's title, the debtors must be notified. This case involved transactions which took place in Philadelphia prior to the enactment of the bookmarking statute:

The Corn Exchange National Bank, for full value, made a loan to the borrower, solely to enable the latter to meet its payroll and other operating expenses, taking as security the assignment of certain of its accounts receivable. The transaction took place with the full knowledge of a creditors' committee, then in charge of the borrower's affairs, but the debtors were not notified of the assignment. More than four months afterward, the borrower was petitioned into bankruptcy, and the trustee then contested the bank's right to the assigned accounts receivable and the proceeds. The case ultimately, in I943, went to the United States Supreme Court, which held (interpreting Section 6oa of the Bankruptcy Act of 1938) that even though the bank had advanced its money in good faith and for value more than four months prior to the bankruptcy, it obtained no title to the assigned accounts as against the trustee. Since the law of Pennsylvania then required notification, the bank's title to the accounts had, technically, not become "perfected" within the meaning of Section 6oa until "immediately prior" to the bankruptcy, with the result that the transaction constituted a preference.

This ruling was received with misgivings by all engaged in commercial financing, particularly as to cases in which the relevant transactions crossed state lines. The assignor might well reside or do business in one state, the assignee in another, and the account-debtors in a third or fourth state: and no one could know which law should apply. The matter was further complicated by the decision of the United States District Court for the Eastern District of Missouri in In re Vardaman Shoe Company. ${ }^{19}$ On the other hand, within the past year, Federal District Judge Guy Fake, in a case arising in New Jersey, has written a strong opinion confining the operation of the doctrine within proper limits. Where a state is involved whose law on the subject is not embodied in a clearly expressed statute or judicial ruling, the entire subject remains in doubt.

In $194 \mathrm{I}$, Ohio became the first state to enact a recording statute. ${ }^{20}$ A somewhat similar law was enacted in California in $1943 .{ }^{21}$ Both states set up technical conditions that must be complied with for any assignment of accounts receivable to be valid as against a trustee in bankruptcy. These state laws require close attention by those engaged in the field of commercial financing; for, while they attempt to promote certainty as to title, they sometimes create new uncertainties which may invite litigation.

The foregoing discussion certainly bears out Messrs. Steffen and Danziger's pre-

${ }^{20} 52$ F. Supp. 562 (E.D. Mo. I943).

${ }^{20}$ OHIo Gen. Code ANN. \$\$8509-3-8509-6 (Supp. 1947).

${ }^{21}$ Cal. Laws 1943, c. 766, approved May 26, 1943, as amended by Laws 1945, c. 295, approved May 8, 1945, as amended by Laws $\times 947, c$. 1047, approved July 2, 1947. 
viously quoted statement that the courts through the years have given the factor "powerful support in the attainment of his purposes." Yet their statement is phrased in such a way that it might be taken to imply disapproval of this legal justification. Then, too, Steffen and Danziger seem to overlook the fact that there are still risks, perils, and hazards for the factor.

With tens of thousands of individual customer's accounts open on the books at all times, and running into millions of dollars, the factor's paramount risk is, of course, from business failures. In times such as the depressions of the Thirties and earlier in the Twenties, bad-debt losses absorbed by factors were extremely heavy. Factors attempt to minimize these severe losses by outside insurance or self-insurance funds. The outside insurance coverage is, of course, excess coverage, with substantial first losses being absorbed by the factor before the insurance benefits become operative. Factors also suffer substantially from losses arising through the inability of clients to meet the payment of loans, and the factor's inability to realize the loaned amount from pledged merchandise or other collateral. In bad times, some customers refuse to accept goods after shipment, or return, for one reason or another, goods already received. This places a severe burden on the manufacturer, who sometimes is unable to realize on such returned merchandise to repay the factor for advances made. Still, old-line factors continue to work sympathetically with the manufacturers to keep their clients in business, and together they work out their difficulties.

For the investigation of new loans and the maintenance of accounts, most factors and finance companies have a staff of accountants and auditors trained in investigation and surveys. The services of these men are available to clients or prospective clients for guidance in factoring and credit problems. While the factor must rely to a great extent upon the reports of independent accountants, either directly or through reporting agencies such as Dun \& Bradstreet, National Credit Office, and the various agencies identified with specific industries, factors are more and more realizing the value of trained accountants on their own staffs to act as liaison between themselves, their clients, and the clients' own independent accountants. Factoring today is essentially a service function. Making available working capital funds is an important feature, but it is by no means the whole story. To be successful today, a factor must make some tangible contribution to the welfare, stabilization, or growth of his client.

Factoring is an institution of honorable tradition and long experience. Its increasing volume and scope, and its many benefits to industry, are its economic justification. It has demonstrated a facility for adapting itself to changing conditions, and there is good reason to believe that it will continue to seek new ways to aid clients in their financial and credit problems, at a cost commensurate with the services rendered and consistent with prevailing business conditions. There is every reason to state that factors will continue to play an increasingly important part in the development of industry. 